УДК 65.011:070

(๖) Л. П. Шендерівська, к.е.н., доцент, М. А. Лисенко, студентка, Н. О. Малиш, студентка, КП। ім. Ігоря Сікорського, Київ, Україна

\title{
РОЗВИТОК МЕДІА В КОНТЕКСТІ КОРПОРАТИЗАЦІЇ
}

\author{
Виявлено структурні зрушення у медіаіндустрії, \\ що зумовлено передусім активізацією розвитку діяль- \\ ності у сфері телевізійного мовлення. Визначено тен- \\ денцію посилення інтеграційних процесів у медіаіндустрії, \\ створення об'єднань підприємств переважно таких сфер \\ діяльності, як інформаційні агентства, видавці періодичних \\ видань, підприємства телевізійного й радіомовлення, \\ продакшн студії. Обґрунтовано основні фактори \\ конкурентоздатності медіакорпорацій.
}
Ключові слова: корпоратизація; холдинг; об'єднання; медіа; медіаіндустрія; видавнича діяльність; телевізійне мовлення; онлайн-видання.

\section{Постановка проблеми}

В сучасних умовах розвитку глобалізованої світової економіки інформація вже давно стала унікальним товаром, що має свій специфічний ринок без кордонів. Медіаіндустрія $€$ окремим динамічним сектором зі своїми характеристиками. Водночас йому властиві й загальносвітові тенденції, зокрема, створення об'єднань з метою збільшення ринкової частки, підвищення якості продукції, диверсифікації діяльності. Так, до наймасштабніших злиттів у видавничому бізнесі можна віднести поєднання у 2013 р. видавничих підрозділів «Penguin Books» (британський медіахолдинг «Pearson») та «Random House» (німецький медіаконцерн «Bertelsmann»): як наслідок об'єднання, видавнича мультинаціональна компанія щорічно випус- кає 15 тис. назв книг [1]. Для порівняння, випуск книг та брошур в Україні у 2017 р. загалом становив 22 тис. назв [2].

Сьогодні стала особливо помітною посилена концентрація мас-медіа у світі. Об'єднання, як правило злиттям, різнопрофільних медіа та інших пов'язаних галузей останнім часом вважається однією з головних тенденцій в індустріально розвинених країнах світу. Процес укрупнення організованостей світової медіаіндустрії нині є істотно значущим, оскільки медіакорпорації й холдинги стали не лише копіювати форми та способи ведення бізнесу непрофільних компаній або конкурентів із суміжних сфер, а й безпосередньо впливати на економічний розвиток та суспільство. Тому предметом нашого аналізу

(C) $2018 \mathrm{p}$. 
$€$ стан розвитку медіа в умовах активізації процесів створення корпоративних об'єднань.

\section{Аналіз попередніх досліджень}

Медіапростір залежить від факторів політичного, економічного, культурного, науково-технічного розвитку - й водночас активно формує ці сфери життя [3, С. 21]. Тенденцією нинішнього медійно орієнтованого суспільства $€$ осмислення глобалізаційних символів як продуктів міжкультурної взаємодії [4, С. 88]. Ба більше, процеси політичної комунікації в сучасних демократичних суспільствах майже у повному обсязі відбуваються через мас-медіа [5, С. 11]. Нові цифрові технології чинять радикальний вплив на розподіл продукції мас-медіа, й у майбутньому цей вплив посилюватиметься [6, С. 44].

В умовах нових медіа продажі малопопулярного контенту можуть перевершити продажі найпопулярнішого, це пояснюється тим, що освоюються незліченні ніші та задовольняються міноритарні смаки, такий економічний ефект має назву «довгий хвіст» [7, C. 144].

Медіакомпанії, виробляючи інформаційні продукти, задовольняють свої економічні інтереси, а також отримують лобістську вигоду, що впливає на рівень їхьооі інвестиційної привабливості [8, С. 45], збереження якої потребує постійної роботи над брендом [9, С. 31]. У сучасних умовах розвивається ко-брендинг, це передусім адаптація міжнародного мас-медіа до місцевих умов, як наслідок, використання добре знаного бренду дозволяє з перших випусків періодичних видань, радіо- та телевізійних передач тощо мати свого споживача [10, С. 232]. Таким чином, динамічність тенденцій, що виникають у медіапросторі, спричиняє структурні трансформації медіа-індустрії, а це актуалізує необхідність комплексно досліджувати означені процеси.

\section{Мета роботи}

Вивчення актуальних тенденцій розвитку медіаіндустрії з визначенням особливостей діяльності її пріоритетної організаційної форми - медіаоб'єднань.

\section{Результати проведених досліджень}

Основні тенденції розвитку медіаіндустрії наснажено передусім економічними й правовими факторами. За даними Державної служби статистики [11], витрати українців на культуру та відпочинок в період з 2010 до 2017 року у структурі загальних кінцевих витрат домашніх господарств скоротились з 1,8 \% до 1,6 \%, що пояснюється інфляційними процесами. Як наслідок, спостерігається зростання питомих витрат на товари першої необхідності; а також розширення доступу до безкоштовного, головно піратського контенту. Зменшилася й частка витрат на освіту (з 1,3 \% до 1,1\%), це пов'язано передусім з поширенням альтернативних сертифікованих безкоштовних онлайн навчальних курсів та освітньою міграцією українців, переважно до Польщі.

Значний вплив на розвиток медіаіндустрії справляє такий її сектор, як видавнича галузь. Як 


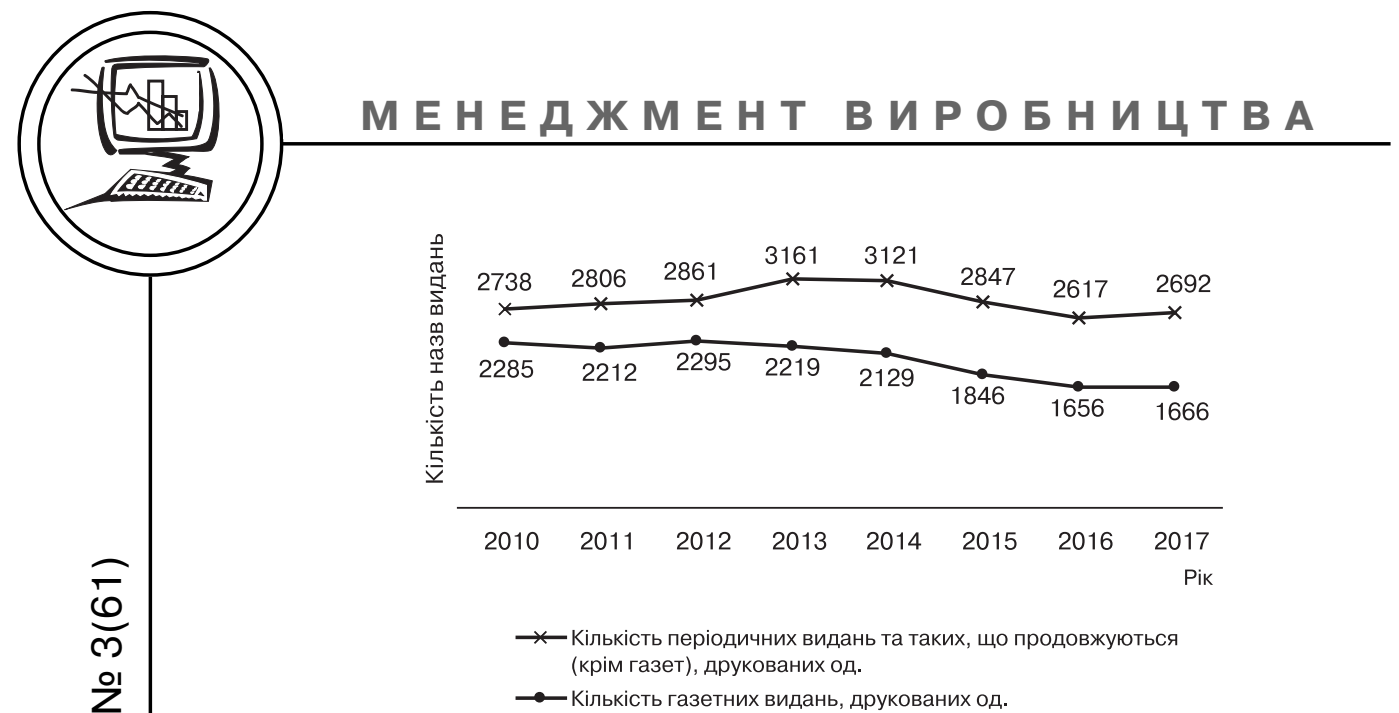

Рис. 1. Динаміка кількості назв періодичних видань за 2010-2017 рр., друкованих од. Джерело: побудовано авторами за даними [11]

показав аналіз, випуск книжкової продукції в Україні за кількістю назв з 2010 до 2017 року знизився на 2,3 \%, загальний наклад залишився відносно стабільним (зріс лише на 0,2 \% [2]). Станом на 2016 рік показники ефективності українських видавництв залежно від їх розміру коливаються від 3,3 \% збитків до 2 \% рентабельності, що хоч і $є$ позитивною динамікою порівняно 3 2010 роком (збитки до 4,5\%) [11], але не сприяе прогресивному розвитку галузі.
Задля більш комплексного визначення трендів у медіаіндустрії дослідимо динаміку випуску в Україні такого виду медіапродукції, як періодичні видання (рис. 1, 2).

За кількістю назв кардинальні зміни відбулися на ринку друкованих газетних видань - спостерігається зниження кількості їх назв на $27 \%$, у той час як на ринку інших періодичних та продовжуваних видань скорочення становило не більше $2 \%$. Ця статистика підтверджує зміщення

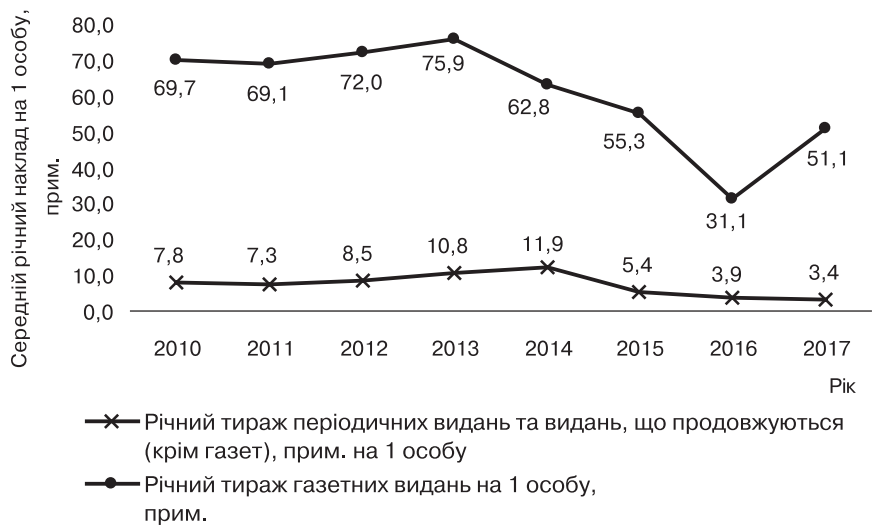

Рис. 2. Динаміка середнього річного тиражу періодичних видань на 1 особу за 2010-2017 рр., прим. Джерело: побудовано авторами за даними [11] 
обсягу попиту, відтак і пропозиції, на користь онлайн-газет. Динаміку ринку періодичних друкованих видань за середнім тиражем представлено на рис. 2.

Як показав аналіз, зміна середнього тиражу газет відбувається симетрично до скорочення кількості їх назв - $27 \%$.

Водночас за показником середнього тиражу істотно - на $56 \%$ зменшився обсяг ринку інших періодичних видань. Тобто, попри зміщення уподобань читачів на користь інтернет-видань, видавці негазетних періодик ґрунтовно вивчають потреби ринку, проводять детальну сегментацію, відтак задовольняють більш диференційований попит, тому за кількістю назв істотних змін за період аналізу не спостережено. Більш якісне задоволення потреб окремих сегментів аудиторії українських періодик й зарубіжних досягається також шляхом e-mail розсилки персоналізованих повідомлень 3 анонсами видань або новин 3 тематики, яка цікавить відповідні цільові аудиторії [9, С. 31]. Успішними проектами на вітчизняному ринку стали не щоденні, а щотижневі видання, а саме ділова та глянцева преса [8, С. 45].

Водночас в умовах скорочення середніх тиражів актуалізується завдання забезпечувати сталі надходження від реклами у доходах видавців. А це стимулює їх готувати більш якісний контент для утримання читацької аудиторії, відтак не допустити й зниження інтересу до періодик з боку рекламодавців. Отже, потребує активізації діяльність у сфері популяризації видань та подання їх контенту у різних форматах, зручних для споживачів, а саме онлайн та офлайн одночасно. Ефективним для видавничої галузі може бути запровадження концепції посередництва в рекламі, яка наразі реалізується у сфері телевізійного мовлення. Так, посередницька компанія «Buy Time», яка має ділових партнерів у 140 країнах світу, закуповує у медіакомпаній України ефірний рекламний час та продає його у формі медіапортфелів різного обсягу й структури.

Медіаіндустрію формують й інші види економічної діяльності. Для визначення стану їх розвинутості проаналізуємо динаміку обсягу реалізованої видавничої продукції (табл.).

За період аналізу у структурі української медіаіндустрії відбулися принципові зміни. Якщо у 2010 р. лідерські позиції за обсягами реалізованої продукції займали «Видавнича діяльність», а також «Виробництво кіно- та відеофільмів, телевізійних програм, видання звукозаписів», то у 2017 р. лідером за рівнем доходу $є$ «Телевізійне мовлення», обсяг якого зріс у 4,4 рази, що актуалізує значення телебачення як провідного медіа в контексті комерційної діяльності. Прогресивний досвід засвідчує, що телевізійні канали мають стратегічні конкурентні переваги, забезпечуючи 24-годинне мовлення та створюючи новинні сайти з їхнім цілодобовим оновленням [9, С. 31], що в подальшому може сприяти активному поширенню онлайн-телебачення.

На основі проведеного дослідження встановлено, що зниження купівельної спроможності населення, викликане економіч- 
ною та політичною нестабільністю в Україні, зумовлює зменшення питомої ваги середнього класу населення, який є основною цільовою аудиторією друкованих видань. Такі структурні зміни викликають зниження попиту на традиційну медіапродукцію - книжкові видання, та вимагають урізноманітнення пропозиції мас-медіа. Таке становище галузі ставить перед підприємствами медіаіндустрії завдання утримати їх конкурентоздатність. Нестабільне економічне зростання, швидка зміна політичної обстановки й пріоритетів рекламодавців - все це призвело до розвитку нових механізмів та тенденцій, серед яких нині стала особливо помітною корпоратизація мас-медіа України й світу загалом.

У світі поширеною формою медіаоб'єднань $€$ холдинги. Згідно із Законом України «Про холдингові компанії в Україні» [12], холдингова компанія - це акціонерне товариство, яке володіє, користується та розпоряджається холдинговими корпоративними пакетами акцій (часток, паїв) двох або більше корпоративних підприємств (господарських товариств), тобто це компанія, що створюється для володіння контрольними пакетами акцій інших підприємств 3 метою контролю за їх діяльністю.

Основною організаційною формою підприємств, що входять до складу медіаоб'єднань в Україні, є ТОВ, тому, відповідно, й регулюються вони Законом України «Про товариства з обмеженою та додатковою відповідальністю». Поняття холдингу в українському законодавстві не згадується як таке, регулюється хіба діяльність материнської компанії Законом України «Про холдингові компанії», тому регулювання діяльності самого об'єднання вимагає якісних змін у законодавстві.

Обсяг реалізованої продукції підприємств медіаіндустрії, млн. грн [11]

\begin{tabular}{|l|l|l|l|l|l|l|l|l|}
\hline $\begin{array}{c}\text { Вид } \\
\text { економічної } \\
\text { діяльності }\end{array}$ & 2010 & 2011 & 2012 & 2013 & 2014 & 2015 & 2016 & 2017 \\
\hline $\begin{array}{l}\text { Видавнича } \\
\text { діяльність }\end{array}$ & 7345,3 & 8934,2 & 8016,4 & 6272,2 & 5338,1 & 5369,1 & 6331,7 & 6407,0 \\
\hline $\begin{array}{l}\text { Виробництво } \\
\text { кіно- та відео- } \\
\text { фільмів, теле- } \\
\text { візійних про- } \\
\text { грам, видання } \\
\text { звукозаписів }\end{array}$ & 8937,7 & 9337,7 & 3228,8 & 3139,9 & 3212,0 & 3859,5 & 5439,7 & 6804,5 \\
\hline $\begin{array}{l}\text { Діяльність у } \\
\text { сфері радіо- } \\
\text { мовлення }\end{array}$ & 290,9 & 650,2 & 265,0 & 213,2 & 235,0 & 233,9 & 335,9 & 333,7 \\
\hline $\begin{array}{l}\text { Діяльність у } \\
\text { сфері телеві- } \\
\text { зійного мов- } \\
\text { лення }\end{array}$ & 1993,4 & 3340,2 & 6495,6 & 6604,7 & 6052,2 & 5620,5 & 6015,2 & 8758,1 \\
\hline
\end{tabular}


Згідно з Єдиним державним реєстром підприємств та організацій України [13], в Україні холдингів медійної галузі немає як таких, проте фактично позиціонують себе медіахолдингами такі об'єднання підприємств: «StarLightMedia», «UMH Group», «InterMediaGroup», «1+1 Media», «MediaGroupUkraine», ТРК «Люкс», «Мультимедіа-інвест груп» та деякі менші.

Зазвичай до складу медіаоб'єднань входять кілька різних організацій, що функціонують у декількох галузях медіаіндустрії: преса, радіо, телебачення та інтернет. Така централізація діяльності дає можливість провадити єдину інформаційну політику, оперативно вирішувати фінансово-економічні питання, оптимізувати витрати, в тому числі економити на адміністративно-технічному персоналі. Наприклад, дизайнери, працівники бухгалтерії, фінансової, планової, рекламної служб можуть бути задіяні в декількох виданнях одночасно - у керівництва 3'являється можливість сконцентрувати творчий потенціал. Крім того, фінансові втрати за окремими напрямами діяльності може бути компенсовано прибутковістю інших проектів об'єднання. Така світова тенденція є властива й для України, наприклад, низький відсоток рентабельності видавництв у межах холдингу «StarLightMedia» покривається послугами оренди обладнання та діяльністю сейлхаузів.

Для найбільших світових медійних корпорацій властиво також створення версій своїх мас-медіа іноземною мовою, що збільшує їхню потенційну аудиторію та стирає кордони між державами в рамках сучасних глобалізаційних процесів, а розширення ринків збуту сприяє збільшенню прибутків.

Як показав аналіз нормативної бази, у деяких країнах на випередження глобалізаційних процесів уже прийнято закони щодо захисту внутрішнього ринку медіа. Тож навіть Китай вирішив сконцентрувати провідні системи мовлення країни в рамках міжнародних медіакорпорацій. Міркуючи на випередження, не іноземних конкурентів там допущено на внутрішній інформаційний ринок, а навпаки Китай протистоїть їхньому тиску на зовнішніх ринкових колах [14].

Українські медіа поступово починають відповідати світовим тенденціям інформаційного ринку, хоча демонструють у тому характерні відмінності. Всупереч світовому підходу до медіа як до бізнесу, в Україні мас-медіа здебільшого використовуються як засіб політичного лобіювання та інформаційного впливу на громадян. Яскравим підтвердженням цього є вільний безкоштовний доступ до більшості каналів отримання інформації (того ж телебачення). Якщо прослідкувати українську тенденцію стосовно належності медіаоб'єднання особі, котра є представником політичної сили, чи олігархові, який не має істотної зацікавленості в отриманні прибутку саме в секторі медіабізнесу, то це переконливо й пояснює брак у наших медіа нейтральності, невиваженість, упередженість у подачі ними інформації, вихід замовних матеріалів, замовчуван- 
Позитивним проявом впливу глобалізації на світові медіа $€$ проникнення професійних західних стандартів у щоденну практику журналістики. Правда, в Україні це передусім стосується графічного оформлення медіаконтенту: верстка, ілюстрації, заголовки - все це робить українські газети й журнали все більше схожими на британські чи американські видання, ніж на пресу радянської епохи.

В постійному прагненні отримати зиск від медіадоступу, як це ведеться в післярадянські часи на просторі екс-СРСР, журналісти в Україні майже перестали зважати на якість контенту в своїх виданнях, тому така ї фінансова залежність негативно впливає на медіапродукт, що отримує як масова телевізійна аудиторія, так й покупці видань. Таким чином, існує потреба у всебічному виваженому поданні

медіаінформації, а критично налаштовані споживачі контенту медіа так чи інак змушені робити власні висновки про явища й події на основі самостійної дефрагментації відомостей. Нині це можна робити доволі якісно навіть нефаховим споживачам медіа, маючи доступ до різних аналітичних оглядів передусім у соціальних мережах: для дорослої аудиторії в Україні - це переважно Facebook та месенджер Telegram.

\section{Висновки}

У підсумку доцільно зазначити, що наслідки глобалізації не просто трансформують українські мас-медіа й спрощують вплив медіа на інститути суспільства та держави, а й змінюють їх структури та способи функціонування. Процес корпоратизації поступово перетворює медіаіндустрію в одну з важливих галузей світової економіки, а медіаоб'єднання - в потужні структурні елементи. Розвиток медіа в Україні залежить від політичного, економічного становища, рівня культури й освіти населення та дотримання в мас-медіа принципів зваженості та незалежності, відношення до інформаційної галузі як до бізнесу, а не суто засобу впливу на маси. Факторами конкурентоздатності підприємств медіаіндустрії $€$ кобрендинг, впровадження провідного професійного досвіду розвинених країн, пропозиція актуального, якісного контенту, задоволення диференційованого попиту, диверсифікація засобів й форм поширення інформації. 


\section{Список використаної літератури}

1. Penguin Random House // Офіційний сайт. URL: https://www.penguinrandomhouse.com.

2. Книжкова палата України // Офіційний сайт. URL: http://www.ukrbook.net.

3. Нові медіа в сучасному суспільстві: культурологічний вимір / [Судакова В. М. та ін.]. Київ: Ін-т культурології НАМ України, 2017. 351 с.

4. Чернявська Л. В. Соціальний простір мас-медіа: монографія / Л. В. Чернявська. Запоріжжя: Запорізький національний університет. 2016. 412 с.

5. Андрійчук М. Т. Взаємодія мас-медіа та органів державної влади: навч. посіб. / М. Т. Андрійчук, Т. С. Андрійчук. Київ: КПІ ім. Ігоря Сікорського, 2018. 114 c.

6. Методологія досліджень мас-медіа: робоча книга / за заг. ред. К. Г. Сіріньок-Долгарьової. Запоріжжя: ЗНУ. 2017. 156 с.

7. Больц Н. Абетка медіа / За заг. ред. В. Ф. Іванів; Переклад з нім. В. Климченка. Київ: Академія української преси, Центр вільної преси. 2015. $177 \mathrm{c}$.

8. Чекалюк В. В. Позиціонування України в сучасних медіа в умовах міжнародних трансформацій: науково-концептуальний та прикладний аспекти: монографія / В. В. Чекалюк. Київ: Паливода А. В. 2017. 148 с.

9. Тангейт М. Медиагиганты: Как крупнейшие медиакомпании выживают на рынке и борются за лидерство / Марк Тангейт: Пер. с англ. Москва: Альпина Бизнес Букс. 2006. 252 с.

10. Сучасні журнали України: типи, властивості, контент: довід.-енцикл. вид. / упорядники Н. М. Сидоренко, О. Ю. Сухомлин; за заг. ред. Н. М. Сидоренко. Київ: ВПЦ «Київський університет». 2015. 367 с.

11. Державна служба статистики України // Офіційний сайт. URL: http://www.ukrstat.gov.ua.

12. Про холдингові компанії в Україні: Закон України від 01 січня 2016 р. № 34 / Верховна Рада України. URL: http://zakon2.rada.gov.ua/laws/ show/3528-15.

13. Єдиний державний реєстр юридичних осіб, фізичних осіб-підприємців та громадських формувань // Офіційний сайт. URL: https://usr.minjust. gov.ua/ua/freesearch.

14. Лебедь Н. Медіахолдинги світу: більші з найбільших / Н. Лебедь // Obozrevatel. 2013. 08 липня. URL: https://www.obozrevatel.com/politics/34916-media-holdingi-svitu-bilshi-z-najbilshih.htm.

15. Малінін В. С. Медіакорпорації в Україні: сучасні реалії розвитку / В. С. Малінін. URL: http://journlib.univ.kiev.ua/index.php?act=article\&article=1234.

\section{References}

1. Penguin Random House // Ofitsiinyi sait. Retrieved from https://www. penguinrandomhouse.com [in English].

2. Knyzhkova palata Ukrainy // Ofitsiinyi sait. Retrieved from http://www.ukrbook.net [in Ukrainian].

3. Sudakova, V. M. etc. (2017). Novi media v suchasnomu suspilstvi: kulturolohichnyi vymir. Kyiv: In-t kulturolohii NAM Ukrainy, 351 p. [in Ukrainian].

4. Cherniavska, L. V. (2016). Sotsialnyi prostir mas-media. Zaporizhzhia: Zaporizkyi natsionalnyi universytet. 412 p. [in Ukrainian]. 
5. Andriichuk, M. T. \& Andriichuk, T. S. (2018). Vzaiemodiia mas-media ta orhaniv derzhavnoi vlady. Kyiv: KPI im. Ihoria Sikorskoho, 114 p. [in Ukrainian].

6. Sirinok-Dolharova, K. H. (2017). Metodolohiia doslidzhen mas-media. Zaporizhzhia: ZNU. 2017. 156 p. [in Ukrainian].

7. Bolts, N. (2015). Abetka media. Kyiv: Akademiia ukrainskoi presy, Tsentr vilnoi presy. 177 p. [in Ukrainian].

8. Chekaliuk, V. V. (2017). Pozytsionuvannia Ukrainy v suchasnykh media v umovakh mizhnarodnykh transformatsii: naukovo-kontseptualnyi ta prykladnyi aspekty. Kyiv: Palyvoda A. V. 148 p. [in Ukrainian].

9. Tangeyt, M. (2006) Mediagigantyi: Kak krupneyshie mediakompanii vyizhivayu na ryinke i boryutsya za liderstvo. Moskva: Alpina Biznes Buks. 252 p. [in Russian].

10. Sydorenko, N. M. \& Sukhomlyn, O. Yu. (2015). Suchasni zhurnaly Ukrainy: typy, vlastyvosti, kontent. Kyiv: VPTs 'Kyivskyi universytet'. 367 p. [in Ukrainian].

11. Derzhavna sluzhba statystyky Ukrainy // Ofitsiinyi sait. Retrieved from http://www.ukrstat.gov.ua [in Ukrainian].

12. Pro kholdynhovi kompanii v Ukraini: Zakon Ukrainy vid 01 January 2016. № 34 / Verkhovna Rada Ukrainy. Retrieved from http://zakon2.rada.gov.ua/ laws/show/3528-15 [in Ukrainian].

13. Yedynyi derzhavnyi reiestr yurydychnykh osib, fizychnykh osib-pidpryiemtsiv ta hromadskykh formuvan // Ofitsiinyi sait. Retrieved from https://usr.minjust.gov.ua/ua/freesearch [in Ukrainian].

14. Lebed, N. (2013) Mediakholdynhy svitu: bilshi z naibilshykh. Obozrevatel, July 08. Retrieved from https://www.obozrevatel.com/politics/34916-media-holdingi-svitu-bilshi-z-najbilshih.htm [in Ukrainian].

15. Malinin,V. S. Mediakorporatsii v Ukraini: suchasni realii rozvytku. Retrieved from http://journlib.univ.kiev.ua/index.php?act=article\&article=1234 [in Ukrainian].

Выявлено структурные изменения в медиаиндустрии, обусловленные прежде всего активизацией развития деятельности в сфере телевизионного вещания. Определено тенденцию усиления интеграционных процессов в медиаиндустрии, создания объединений предприятий преимущественно таких сфер деятельности, как информационные агентства, издатели периодических изданий, предприятия телевизионного и радиовещания, продакшн студии. Обосновано основные факторы конкурентоспособности медиакорпораций.

Ключевые слова: корпоратизация; холдинг; объединение; медиа; медиаиндустрия; издательская деятельность; телевизионное вещание; онлайн-издание.

Structural shifts in the media industry are revealed, which is primarily due to the intensification of the deve- 
lopment of activities in the television broadcasting.

The tendency of strengthening of integration processes in the media industry, establishment of enterprise associations mainly in such spheres of activity as news agencies,

publishers of periodicals, enterprises of television and radio broadcasting, production studios are determined. The main factors of the competitiveness of media corporations are substantiated.

Keywords: corporatization; holding; association; media; media industry; publishing activity; television broadcasting; online edition.

Рецензент - О. М. Левчук, к.філол.н., доцент, КПІ ім. Ігоря Сікорського 